\title{
POTENSI DAN PERMASALAHAN PENGEMBANGAN PERKEBUNAN KELAPA SAWIT SKALA BESAR DI KALIMANTAN TIMUR
}

\author{
Oleh: Santo Adhynugraha ${ }^{8}$
}

\begin{abstract}
East Kalimantan is one of wealthiest and widest provinces in Indonesia having strategic position, either geographically or economically. It is characterized by prosperous natural resources such as vast deposit of mining and energy, oceanic and forest resources, and so forth. As a well-off province, good and sound management is truly required to improve public prosperity as well as to guard ecological quality. One of the most probable potency is palm oil plantation. The availability of bountiful land in Kalimantan makes the efforts of building large-scale palm oil plantation more reliable. However, discourse on the operation of the one-million-hectare-palm-oil-plantation is awfully dilemmatic. There is no symmetric concordance between 'pros' and 'cons' so far. The government policy on promoting plantation sector, therefore, is still blurred. Based on such situation, this paper tries to explore and evaluate the government plan to develop large-scale oil palm plantation in East Kalimantan province, especially from the perspective of public policy.
\end{abstract}

Keywords: kebijakan, kelapa sawit, Kalimantan Timur.

\section{Pendahuluan}

Beberapa waktu terakhir ini semakin marak perbincangan tentang rencana kebijakan Pemerintah untuk melakukan pengembangan perkebunan kelapa sawit skala besar di wilayah Kalimantan dan khususnya Kalimantan Timur. Mulai dari pendapat para pakar dan pejabat dalam media pemberitaan lokal maupun nasional, lokakarya dan seminar oleh berbagai pihak yang berkepentingan langsung maupun tidak, hingga aksi demonstrasi menyatakan pendapat secara langsung oleh beberapa aktifis dengan mengatasnamakan organisasi ataupun golongan tertentu. Pihak-pihak tersebut terlibat dalam pertentangan antara pihak yang pro (mendukung) dan pihak yang kontra (menolak). Yang menjadi perdebatan tidak hanya masalah luasan lahan yang dikembangkan sebagai areal perkebunan yang terbilang sangat besar mencapai

Santo Adhynugraha, S.Si adalah Staf Peneliti bidang Kajian Aparatur pada Pusat Kajian dan Pendidikan dan Pelatihan Aparatur III Lembaga Administrasi Negara, Samarinda. 
jutaan hektar, namun pilihan komoditas, lokasi pembangunan, proses dan teknis pengelolaan, hingga dampak bagi lingkungan dan masyarakat.

Bagi pihak yang mendukung, pengembangan perkebunan kelapa sawit skala besar tersebut perlu dilakukan guna meningkatkan perekonomian negara dan juga mengembangkan wilayah di Kalimantan yang cukup luas namun belum berkembang dengan baik, bahkan banyak daerah-daerah tertentu terutama di pedalaman yang masih terisolir karena sarana penghubung dengan daerah lainnya belum tersedia dengan baik. Selain itu sumberdaya alamnya mengalami kerusakan semakin parah akibat ulah pihak-pihak yang hanya mengambil keuntungan dengan mengambil hasil hutan dan meninggalkan lahan-lahan yang telah gundul dan rusak begitu saja, sedangkan masyarakat disekitarnya tidak berdaya dan hanya menjadi saksi hidup terjadinya kerusakan alam di sekitar mereka karena jumlah dan kemampuan mereka terbatas, bahkan cenderung untuk turut terlibat merusak alam karena desakan kebutuhan ekonomi. Diharapkan dengan dibukanya lahan perkebunan di daerahdaerah tersebut dapat membuka keterisolasian daerah dan meningkatkan kegiatan perekonomian sehingga akan meningkatkan kesejahteraan masyarakat.

Sedangkan pihak yang menolak, melihat kegagalan dari kebijakan-kebijakan sejenis sebelumnya yang ternyata hanya mengambil hasil hutannya dan meninggalkan begitu saja lahan terlantar yang menyimpan potensi bencana sampai ke hilir sungai yang banyak merupakan daerah perkotaan, seperti banjir dan kekeringan. Mereka juga berpendapat bahwa kelapa sawit juga bukan merupakan komoditas yang dapat dikembangkan di semua lahan karena sifatnya yang "rakus air" sehingga dikhawatirkan akan mengganggu persediaan air di wilayah yang merupakan daerah resapan dan kantong-kantong air, belum lagi dampak dari limbah minyak sawit yang dapat mencemari lingkungan jika tidak dikelola secara baik dan benar. Selain itu, tidak ada jaminan bahwa dengan pengembangan perkebunan kelapa sawit dapat membawa kesejahteraan bagi masyarakat di sekitarnya.

Pengembangan perkebunan kelapa sawit ini sebenarnya sudah dilakukan oleh pemerintah sejak lama dan semakin gencar dilakukan seiring dengan perubahan sistem pengelolaan daerah dan kewenangan dengan adanya otonomi daerah. Dimana masing-masing pemerintah daerah yang mempunyai lahan yang cukup berusaha mengembangkan komoditas sawit yang memang peluang dan kebutuhan pasarnya masih sangat besar sehingga banyak daerah yang menjadikannya sebagai komoditas unggulan dan terus dikembangkan. Namun, belakangan ini terjadi perkembangan wacana tentang pengembangan perkebunan kelapa sawit untuk daerah perbatasan Kalimantan dan Malaysia. Tentunya hal ini perlu ditanggapi secara arif dan bijaksana, mengingat arah kebijakan tersebut tidak lagi hanya peningkatan perekonomian namun juga politik dan keamanan terutama di daerah perbatasan. Hal ini sangat menyedot perhatian banyak pihak dengan berbagai sudut pandang yang berbeda dalam menanggapi kebijakan ini. Bahkan sejak awal rencana kebijakan ini telah mendapat respon yang beragam mulai dari dukungan, penolakan bahkan demo dari kalangan aktivis lingkungan.

Jika dilihat secara positif, adanya perdebatan dan perbedaan pendapat tersebut merupakan proses demokratis dan pembelajaran bagi semua pihak, bahwa dalam suatu 
strategi pengembangan kebijakan terutama yang berkaitan dengan pengembangan suatu wilayah hendaknya dilakukan suatu proses yang baik dan terencana secara detail dan terperinci sejak awal adanya wacana tersebut dengan dilengkapi sumber dan data-data akurat sebagai dasar dalam membuat suatu kebijakan. Bahkan sebenarnya dari perbedaan pendapat tersebut dapat dilakukan konsiliasi guna mendapatkan hasil yang mengakomodasi pendapat berbagai pihak, asalkan semua pihak bersedia untuk saling menerima masukan guna memperoleh keputusan yang terbaik dan tepat dimana di satu sisi dapat meningkatkan perekonomian masyarakat dan bangsa dan di lain sisi kelestarian kekayaan hutan tropis Kalimantan juga dapat turut terjaga.

Tabel 1. Perkembangan Produksi Kelapa Sawit

\begin{tabular}{|c|c|c|}
\hline TAHUN & LUAS AREAL (Ha) & PRODUKSI (Ton) \\
\hline 1997 & $68.622,00$ & 398.581 \\
1998 & $91.571,00$ & 226.898 \\
1999 & $116.887,50$ & 356.102 \\
2000 & $116.887,50$ & 433.645 \\
2001 & $117.055,00$ & 466.729 \\
2002 & $132.173,50$ & 760.243 \\
2003 & $159.079,00$ & 791.064 \\
2004 & $172.547,00$ & 833.323 \\
2005 & $197.301,00$ & 1.053 .317 \\
\hline ** Pertumbuhan luas areal perkebunan kelapa sawit rata-rata 21,9 persen/tahun \\
Pertumbuhan produksi perkebunan kelapa sawit rata-rata 16,32 persen/tahun
\end{tabular}

Sumber: Tribun Kaltim, 6 Maret 2006 
Tabel 2. Industri Perkebunan Kelapa Sawit Di Kalimantan Timur

\begin{tabular}{|c|l|l|l|}
\hline No. & \multicolumn{1}{|c|}{ Nama Perusahaan } & \multicolumn{1}{|c|}{ Kapasitas } & \multicolumn{1}{|c|}{ Lokasi Pabrik } \\
\hline 1. & PT. REA Kaltim Plantation & 80 ton TBS/jam & Kec.Kb.Janggut, Kab.Kutai Kert. \\
2. & PT. Swakarsa Sinar Sentosa & 45 ton TBS/jam & Kec.Muara Wahau, Kab.Kutai Timur \\
3. & PT. Matra Sawit Sejahtera & 30 ton TBS/jam & Kec.Muara Wahau, Kab.Kutai Timur \\
4. & PTPN XII & 30 ton TBS/jam & Desa Semuntai, Kab.Pasir \\
5. & PTPN XII & 60 ton TBS/jam & Desa Long Pinang, Kab.Pasir \\
6. & PTPN XII & 60 ton TBS/jam & Desa Long Kali, Kab. Pasir \\
7. & PT. Waru Kaltim Plantation & 30 ton TBS/jam & Kec.Waru, Kab.Penajam PU \\
8. & PT. Nunukan Jaya Lestari & 30 ton TBS/jam & Kec.Nunukan, Kab.Nunukan \\
9. & PT. Etam Bersama Mandiri & 15 ton TBS/jam & Kec.Kongbeng, Kab.Kutim \\
10. & PT. AB Dharma Nusantara & 30 ton TBS/jam & Kec.Kuaro, Kab.Pasir \\
11. & PT. Comismar Wanamaja & 15 ton TBS/jam & Kec.Lumbis \\
\hline
\end{tabular}

Sumber: Tribun Kaltim, 6 Maret 2006

\section{Perkembangan Kelapa Sawit}

Kelapa sawit (Elaeis guineensis) sebenarnya telah lama dikenal. Menurut sejarah, pada awalnya penyebaran kelapa sawit dari Afrika ke Eropa oleh para penjelajah Portugis terjadi pada tahun 1435. Di Indonesia, kelapa sawit sebenarnya bukan komoditas baru. Tanaman asli Afrika Selatan ini masuk ke Indonesia tahun 1848 pada jaman VOC oleh orang Belanda yang menanamnya di Kebun Raya Bogor. Perkembangannya sebagai komoditas perkebunan dan pemasok bahan baku industri minyak masak, sabun, margarin dan berbagai produk lainnya demikian pesat sejak pertengahan abad XX lalu. Kemudian, budidaya kelapa sawit secara komersial di Indonesia oleh Penjajah Belanda dilakukan pada tahun 1910. Sedangkan budidaya kelapa sawit secara komersial di Malaysia oleh para pedagang Inggris dilakukan pada tahun 1920. Kemudian di Indonesia dilakukan nasionalisasi perkebunan peninggalan penjajah Belanda oleh Pemerintah pada tahun 1957, lalu pada tahun 1968 dilakukan penanaman kelapa sawit berskala besar pertama di Indonesia (PTP) dan pada tahun 1979 dilakukan pengoperasion Perkebunan kelapa sawit Inti Rakyat (PIR) dan perkebunanperkebunan kelapa sawit swasta berskala besar. Puncak kinerja bisnis kelapa sawit di Indonesia terjadi tahun 1990, dimana perkembangannya seiring dengan intensifikasi pembangunan ekonomi nasional melalui pengelolaan sumberdaya alam, termasuk hutan di luar Pulau Jawa seperti di Sumatera, Kalimantan, Sulawesi, dan Papua yang mencakup perkebunan milik negara, perkebunan rakyat, dan perkebunan swasta skala besar. 
Perluasan areal perkebunan kelapa sawit semakin gencar dilakukan sebagai respon terhadap kebutuhan minyak masak domestik maupun ekspor seiring dengan peningkatan populasi dan mahalnya alternatif minyak masak lainnya (antara lain minyak kedelai dan lobak). Ekspansi sawit progresif dan besar-besaran ke Indonesia bagian Timur sebenarnya sudah dicanangkan sejak akhir masa pemerintahan Presiden Soeharto, yang dilanjutkan semasa jaman Presiden Habibie (1998/1999). Kondisi ini dipicu oleh keinginan pemerintah pada waktu itu untuk mengalahkan Malaysia sebagai produsen minyak sawit terbesar di dunia dengan rencana untuk menggandakan luasan kebun menjadi 5,5 juta ha pada akhir tahun 2000. Para investor domestik dan perkebunan-perkebunan swasta milik asing ditawarkan untuk melakukan pengembangan perkebunan.

Ada beberapa kondisi yang menguntungkan bagi industri minyak sawit Indonesia, yaitu mutu minyak sawit Indonesia tidak kalah dari Malaysia dan Industri makanan di Amerika Serikat mulai beralih dari minyak kacang kedelai ke minyak sawit sehingga peluang pasarnya masih sangat besar. Namun, persaingan pasar minyak kelapa sawit juga cukup tinggi dimana berbagai negara yang mempunyai lahan juga membuka perkebunan kelapa sawit seperti Malaysia, Nigeria, Thailand, Brazil, Columbia, Belgia, Gabon, Gana, dan lainnya. Terutama Malaysia yang saat ini menjadi Negara penghasil minyak sawit terbesar di dunia, dimana mereka telah memiliki perkebunan sawit yang cukup luas dilengkapi dengan pabrik pengolah sawit yang cukup besar dan dengan standar pengolahan yang baik sehingga produknya dapat diterima pasar dunia. Indonesia sendiri sebenarnya dapat bersaing karena permintaan terhadap minyak sawit masih sangat besar karena produk olahan dan turunan dari minyak sawit tersebut sangat banyak, bahkan sekarang telah ditemukan cara pengolahan minyak sawit untuk menggantikan solar sebagai bahan bakar mesin diesel yang kini persediaan minyak bumi semakin menipis dan minyak sawit dapat dijadikan alternatif pengganti (biodiesel) yang tentunya sangat besar peluang pasarnya. Sementara itu lahan di Indonesia masih sangat luas yang dapat dimanfaatkan sebagi lahan perkebunan kelapa sawit, selain itu juga tenaga kerja Indonesia masih sangat banyak, bahkan banyak tenaga kerja Indonesia yang bekerja di perkebunan kelapa sawit Malaysia, sedangkan Malaysia sebagai saingan utama Indonesia memiliki keterbatasan lahan dan juga tenaga kerja. Sehingga pada prinsipnya Indonesia memiliki potensi yang besar untuk bersaing dalam Industri kelapa sawit dunia. 


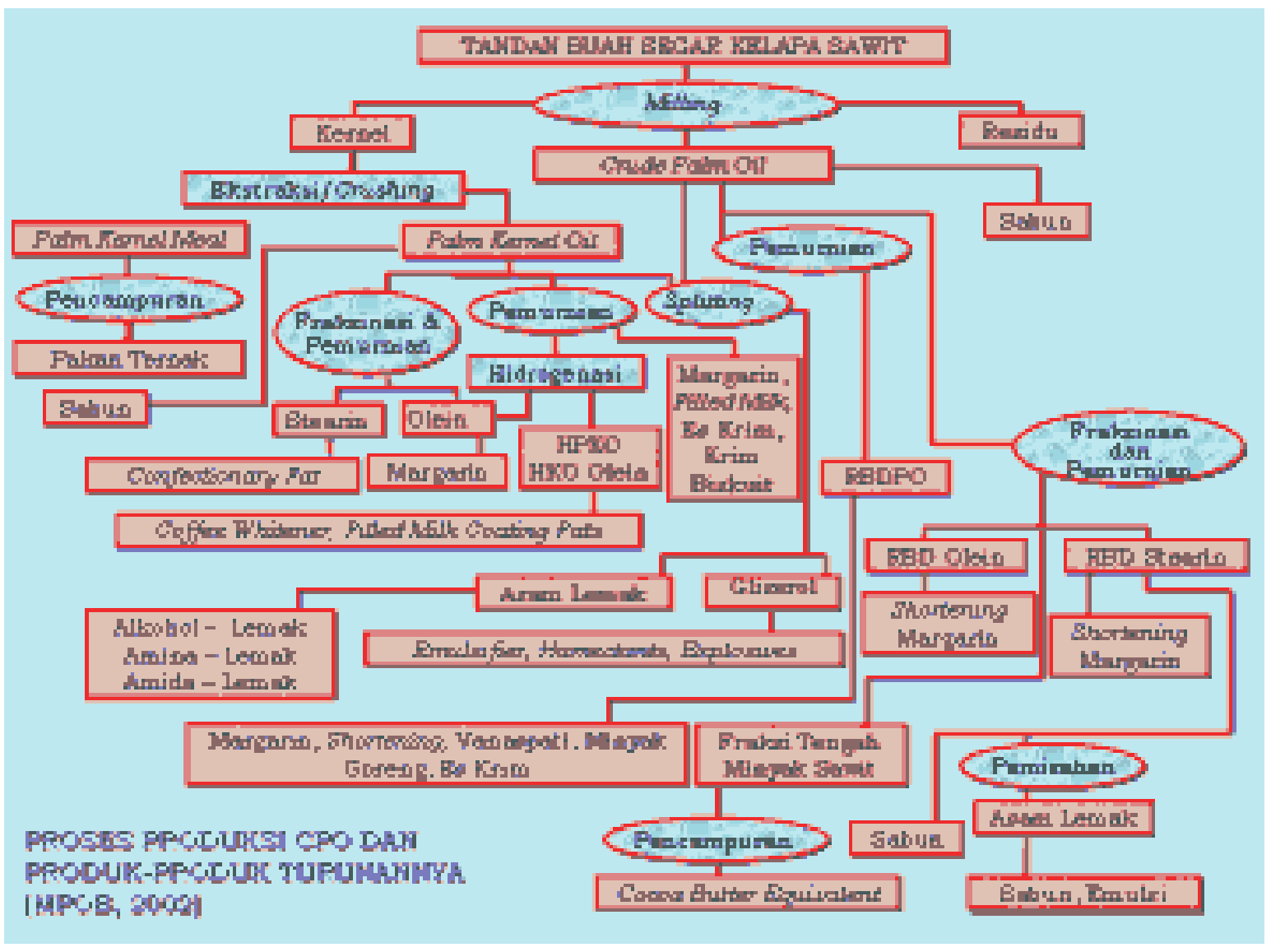

Sumber: Presentasi E. Gumbira Said dalam Seminar SANKRI, 18 Mei 2006

Jika dilihat dari peluang pasar minyak sawit memang masih sangat besar dimana terjadi trend peralihan industri makanan terutama di Amerika Serikat dari minyak kacang kedelai ke minyak sawit dengan berbagai pertimbangan yang lebih menguntungkan, walaupun hal ini sendiri mendapat berbagai tentangan yang menyatakan bahwa kelapa sawit lebih tidak ramah lingkungan sehingga dapat merusak kelestarian alam karena sifatnya yang banyak menyerap air.

Di Kalimantan, kecenderungan peningkatan semakin besar terjadi menjelang implementasi Otonomi Daerah pada tahun 2001 hingga saat ini dimana banyak daerah yang membuat program pengembangan perkebunan kelapa sawit bahkan dengan skala yang cukup luas, dan terakhir adalah adanya rencana Pemerintah untuk mengembangkan sekitar 1,8 juta hektar di daerah perbatasan Kalimantan untuk perkebunan kelapa sawit yang mendapat berbagai respon baik yang mendukung maupun yang menolak rencana tersebut.

\section{Pengembangan Kelapa Sawit Skala Besar dan Pemanfaatan Lahan Kritis}

Program Pemerintah mengembangkan kelapa sawit dalam skala besar merupakan upaya pemerintah dalam rangka mencari komoditas unggulan dari sektor perkebunan yang 
merupakan sumber daya alam yang dapat diperbaharui guna meningkatkan perekonomian bangsa dan negara, dimana selama ini masih sangat tergantung dengan sumber daya alam yang habis pakai (nonrenewable) seperti migas dan pertambangan yang suatu saat pasti akan habis. Upaya Pemerintah dalam mengembangkan perkebunan kelapa sawit gencar dilakukan karena memang mempunyai potensi yang besar dan menjanjikan baik bagi Pemerintah, pengusaha maupun masyarakat yang terlibat dalam usaha perkebunan ini.

Sementara itu lahan kritis yang terdapat di Kalimantan Timur telah mencapai 6,4 juta hektar. Lahan kritis ini disebabkan berbagai hal baik akibat bencana alam seperti kekeringan dan kebakaran hutan, erosi, tanah longsor dan banjir, serta kerusakan lahan akibat dilakukan secara sengaja oleh pihak-pihak tertentu yang ingin mengambil keuntungan dari hasil hutan mulai dari skala kecil seperti pembukaan lahan perladangan oleh masyarakat, sampai skala besar seperti pembukaan HPH yang kemudian setelah kayunya habis lahan tersebut ditelantarkan, pembukaan lahan perkebunan sawit yang juga diterlantarkan setelah hasil hutannya habis, hingga pembalakan liar (illegal logging) yang terjadi baik oleh masyarakat sekitar, aparat sampai oleh cukong dari negara tetangga.

Untuk itulah Pemerintah berupaya menanggulangi luasnya lahan kritis yang ada karena jika tidak segera dilakukan upaya penanggulangan lahan tersebut maka lahan kritis tersebut menyimpan potensi bencana yang sangat besar dan mengancam kelangsungan alam dan juga masyarakat disekitarnya bahkan sampai masyarakat perkotaan akibat hutan yang gundul. Saat ini saja sudah dapat kita lihat bencana banjir yang semakin meluas di berbagai daerah bahkan didaerah yang sebelumnya tidak pernah banjir pun kini mulai terendam dikala hujan turun, karena daerah hutan yang tadinya menjadi resapan air sudah banyak yang gundul sehingga air akan langsung mengalir ke daerah yang lebih rendah.

Melihat dari kenyataan tersebutlah Pemerintah melakukan inisiatif melalui berbagai kebijakan yang dilakukan mulai dari penutupan beberapa perusahaan HPH yang merusak alam dan lingkungan, razia dan pengawasan terhadap praktek illegal logging sampai dengan mencari alternatif penggunaan lahan kritis dengan penanaman kembali lahan kritis tersebut. Namun, untuk melakukan penanaman kembali lahan kritis tersebut diperlukan dana dan tenaga yang besar dimana Pemerintah mempunyai keterbatasan dalam hal ini. Di lain sisi, ada beberapa komoditas perkebunan yang dapat menjadi pilihan untuk ditanami di areal tersebut, diantaranya karet, kakao, kopi, coklat, kelapa sawit dan komoditas perkebunan lainnya.

Namun, dilihat dari peluang pasar dan berbagai produk yang bisa dihasilkan, memang kelapa sawit menjadi pilihan yang sangat menarik bagi Pemerintah, hal ini bisa dilihat dari maraknya program pembukaan lahan kelapa sawit yang dilakukan baik itu program Pemerintah Pusat maupun Pemerintah daerah. Bahkan hal ini semakin banyak dilakukan seiring dengan era otonomi daerah, dimana masing-masing kepala daerah berlomba-lomba untuk mencari pendapatan daerahnya untuk meningkatkan kesejahteraan masyarakat dengan berbagai cara. Salah satunya dengan pemberian ijin pembukaan lahan untuk perkebunan, dan yang banyak adalah untuk perkebunan kelapa sawit. 
Di Kalimantan, khususnya Kalimantan Timur beberapa daerah telah melakukan proyek penanaman kelapa sawit skala besar seperti proyek penanaman kelapa sawit 1 juta hektar dengan memberikan ijin kepada perusahaan-perusahaan swasta untuk mengelola suatu areal tertentu sebagai perkebunan kelapa sawit, selain itu juga pemerintah dan perusahaan memberdayakan masyarakat daerah disekitar perkebunan dengan pola kemitraan dengan menanam kelapa sawit di lahan milik masyarakat dan pemasarannya dikelola melalui perusahaan tersebut, sehingga dapat memberdayakan masyarakat.

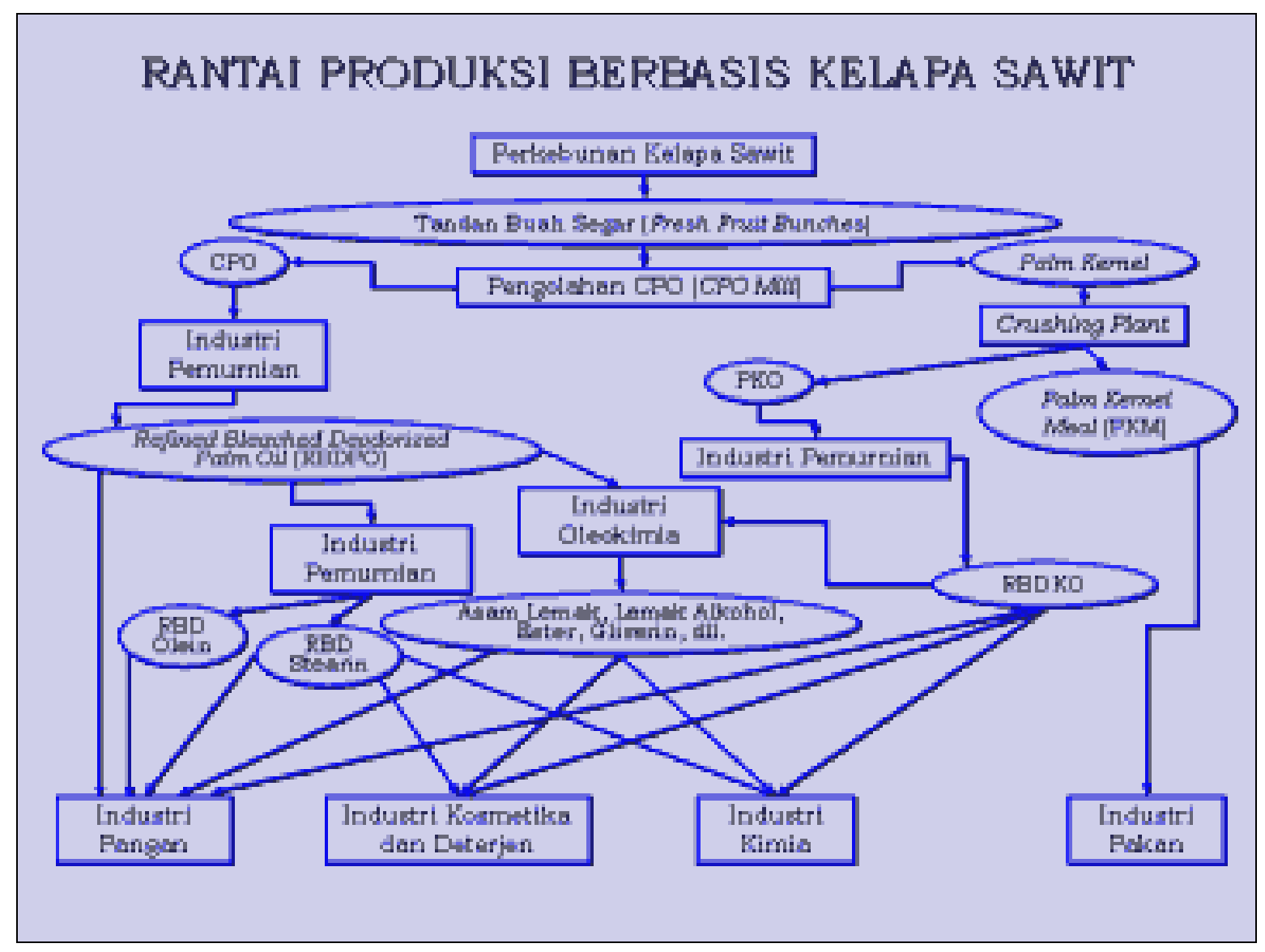

Sumber: Presentasi E. Gumbira Said dalam Seminar SANKRI, 18 Mei 2006

Namun perlu diperhatikan pula bahwa tidak semua lahan cocok untuk ditanami kelapa sawit, karena sifatnya yang membutuhkan banyak air serta spesifikasi lainnya sehingga perlu pemilihan lahan yang sesuai dan tidak mengakibatkan gangguan terhadap keseimbangan ekosistem serta kerusakan lingkungan.

Dalam Keputusan Menteri Kehutanan dan Perkebunan No: 376/Kpts-Ii/1998 tentang kriteria penyediaan areal hutan untuk perkebunan budidaya kelapa sawit, kawasan hutan yang dapat dilepaskan menjadi usaha perkebunan budidaya kelapa sawit adalah kawasan hutan yang berdasarkan kesesuaian lahannya cocok untuk perkebunan budidaya kelapa sawit. Kesesuaian lahan yang cocok untuk perkebunan budidaya kelapa sawit sebagaimana dimaksud dengan kriteria sebagai berikut:

a. Kelerengan $\max 25 \%$. 
b. Ketinggian 0-300 $\mathrm{m}$ dpl.

c. Curah hujan 1750-4000 mm/tahun dengan rata-rata bulan kering per tahun 0-3 bulan.

d. Kedalaman efektif tanah:

- Untuk tanah mineral $>100 \mathrm{~cm}$

- Untuk ketebalan tanah gambut $<200 \mathrm{~cm}$

e. Temperatur rata-rata per tahun $24^{\circ}-29^{\circ} \mathrm{C}$

\section{Pro Kontra Pengembangan Kelapa Sawit Dalam Optik Kebijakan Publik}

Berdasarkan berbagai pendapat dan opini yang berkembang ada beberapa poin penting mengenai alasan yang mendukung rencana pengembangan perkebunan kelapa sawit di Kalimantan, yaitu:

1. Menyediakan lapangan pekerjaan baru yang dapat menyerap banyak tenaga kerja sehingga dapat mengurangi pengangguran dan mengurangi TKI Ilegal ke Malaysia karena dapat bekerja di perkebunan ini.

2. Memperkecil kesenjangan ekonomi antara warga Indonesia dan Malaysia di wilayah perbatasan karena dapat membantu percepatan pembangunan wilayah perbatasan sehingga meningkatkan kesejahteraan bagi masyarakat di daerah perbatasan.

3. Mempercepat pembangunan infrastruktur daerah perbatasan sehingga membuka isolasi wilayah perbatasan dari wilayah lainnya.

4. Mencegah terjadinya illegal logging karena dengan adanya pembangunan perkebunan sawit di daerah perbatasan akan meningkatkan kegiatan perekonomian dan juga membuka akses jalan yang dapat menunjang pengawasan daerah perbatasan oleh pihak yang berwenang.

5. Memanfaatkan lahan secara maksimal, terutama lahan yang terlantar dan lahan tidur dan memperbaiki kerusakan lingkungan yang diakibatkan oleh penebangan hutan secara liar (deforestasi) yang telah banyak terjadi di daerah perbatasan dengan ditanami kembali.

6. Meningkatkan kegiatan sosial ekonomi yang juga mendukung kegiatan pertahanan keamanan di daerah perbatasan dan memudahkan melakukan pengawasan terhadap pelintas batas sehingga secara tidak langsung dapat mempertahankan wilayah Negara Kesatuan RI.

7. Menambah penghasilan devisa bagi negara dari sektor perkebunan.

8. Membantu percepatan pembangunan wilayah baru di daerah perbatasan Kalimantan.

9. Akan membentuk basis perekonomian baru di daerah perbatasan seiring dengan banyaknya tenaga kerja yang ada.

10. Sebagai garis batas, sehingga tidak lagi terjadi pergeseran batas-batas wilayah dan mempermudah penjagaan keamanan perbatasan.

Sedangkan jika dilihat dari sudut pandang yang berbeda, ada beberapa komentar yang tidak sependapat mengenai rencana pembukaan lahan kelapa sawit di kawasan perbatasan. Beberapa point penting alasan penolakan yang terjadi dengan adanya pengembangan perkebunan kelapa sawit di daerah perbatasan Kalimantan adalah:

1. Bertabrakan dengan beberapa wilayah yang merupakan Taman Nasional dan Hutan Lindung di sepanjang kawasan perbatasan, seperti Taman Nasional Kayan Mentarang, Batang Ai dan Betung Kerihun.

2. Adanya potensi konflik sosial, dengan adanya pekerja pendatang dari wilayah lain yang berbeda sosial budaya dari penduduk asli, sehingga penduduk asli akan tersisih oleh 
banyaknya pendatang sedangkan penduduk asli di daerah perbatasan jumlahnya hanya sedikit.

3. Adanya potensi konflik antar masyarakat sekitar karena berebut klaim atas kepemilikan wilayah yang akan di buka sebagai perkebunan kelapa sawit guna memperoleh ganti rugi atas tanah yang dimiliki masyarakat.

4. Alih fungsi hutan di perbatasan akan mengakibatkan kehilangan nilai kayu dan kerusakan lingkungan yang sangat berharga akibat pembukaan lahan untuk perkebunan.

5. Tingkat pembalakan liar semakin meningkat karena akses jalan yang semakin mudah di tambah dengan kegiatan pembukaan lahan perkebunan dan jalan yang juga menebangi hutan.

6. Dapat mengancam keberadaan sumber-sumber air karena daerah perbatasan merupakan daerah tangkapan dan kantong-kantong air sehingga dapat terjadi krisis air di daerah perbatasan akibat diserap oleh Kelapa Sawit yang merupakan tanaman yang menyerap banyak air.

7. Terjadi pendangkalan pada sungai-sungai akibat kerusakan alam di daerah perbatasan karena daerah perbatasan merupakan hulu sungai yang ada di Kalimantan, akibatnya transportasi sungai yang banyak terdapat di Kalimantan akan terhambat dan juga dapat menyebabkan banjir.

8. Kekayaan hayati alam akan hilang akibat pembukaan lahan perkebunan karena Pulau Kalimantan merupakan daerah dengan kekayaan hayati yang beragam dan merupakan paru-paru dunia.

9. Kondisi lahan daerah perbatasan tidak cocok untuk perkebunan kelapa sawit yang cocoknya untuk daerah yang datar, sedangkan daerah perbatasan merupakan daerah pegunungan dan berbukit-bukit.

10. Apabila dalam pelaksanaannya tidak secara baik dimana para investor yang mengerjakan perkebunan hanya mengambil kayu hasil hutan dan tidak melakukan pembangunan perkebunan dengan berbagai alasan seperti terkendala infrastruktur dan pelepasan lahan seperti yang banyak terjadi sebelumnya di beberapa wilayah, maka akan menambah lahan kritis yang ada di Kalimantan.

Terlepas dari adanya kontroversi yang berkembang, rencana kebijakan Pemerintah ini nampaknya tidak terkomunikasikan secara efektif dengan berbagai pihak terkait, sehingga menimbulkan perbedaan penafsiran yang cukup tajam serta mengandung potensi terjadinya kegagalan dalam tahapan implementasi. Akibatnya, terjadilah implementation gap, yakni suatu keadaan dimana dalam proses kebijakan selalu terbuka kemungkinan terjadinya perbedaan antara yang diharapkan dengan yang senyatanya dicapai. Besar kecilnya kesenjangan yang bisa dikatakan sebagai kegagalan itu sendiri ditentukan oleh implementation capacity dari organisasi atau pihak yang diberi tugas melaksanakan kebijakan tersebut. Dalam hal ini, kegagalan kebijakan (policy failure) secara umum terdiri dari dua kategori, yaitu tidak dapat terimplementasikan (non implemented); dan tidak terimplementasi dengan sempurna (unsuccesful implementation).

Setiap kebijakan selalu mengandung resiko kegagalan, termasuk kebijakan pembukaan lahan kelapa sawit skala besar di Kalimantan. Dalam hal ini, untuk dapat mengimplementasikan kebijakan negara secara sempurna (perfect implementation), diperlukan syarat-syarat sebagai berikut: 
1. Kebijakan yang akan diberlakukan didasari oleh suatu kebutuhan dan hubungan kausalitas yang jelas. Artinya, suatu kebijakan harus mampu secara relatif mengatasi permasalahan aktual yang sedang dihadapi.

2. Adanya pemahaman yang mendalam terhadap tujuan dan kesepakatan antar aktor kebijakan. Ini berarti bahwa suatu kebijakan harus mampu memberikan manfaat nyata secara positif dan konstruktif bagi semua pihak secara merata.

3. Adanya komunikasi dan koordinasi yang sempurna sejak tahap formulasi hingga implementasi kebijakan.

4. Dilengkapi dengan instrumen untuk memprediksi dampak-dampak negatif yang mungkin timbul beserta alternatif pemecahannya. Dengan kata lain, suatu kebijakan perlu diidahului oleh suatu kajian akademis yang cukup komprehensif.

5. Harus memiliki daya akseptabilitas dan aplikasi yang tinggi, serta memiliki konsistensi dengan kebijakan terkait dan mampu menghindarkan kemungkinan terjadinya diskriminasi dalam implementasi.

Dalam kasus kebijakan pengembangan kelapa sawit, kontroversi yang hingga saat ini belum menemukan titik temu menggambarkan bahwa kebijakan tadi tidak memenuhi ke-5 kriteria untuk sebuah kebijakan yang baik. Untuk itu, yang perlu dilakukan adalah bukan menarik/membatalkan kebijakan yang ada, atau sebaliknya memaksakan kepada pihak-pihak yang tidak mendukung; tetapi bagaimana melakukan dialog kreatif atau komunikasi sejajar secara terbuka yang bermuara pada tercapainya pemahaman dan saling pengertian diantara berbagai pihak. Kondisi inilah yang diyakini merupakan prakondisi untuk berjalannya sebuah kebijakan secara produktif dan berkesinambungan.

Dalam konteks mendorong lahirnya kebijakan pengembangan kelapa sawit yang sinergis, maka beberapa prakondisi perlu disiapkan secara matang. Salah satu hal yang sangat strategis adalah adanya kejelasan dan ketegasan konsep tata ruang wilayah, sehingga pengembangan kelapa sawit benar-benar sesuai dengan peruntukan yang disusun berdasarkan karakteristik wilayah tanpa mengorbankan kepentingan lingkungan. Untuk itu, aspek AMDAL dalam pembukaan kelapa sawit skala besar juga harus diperhatikan dengan serius.

Sementara itu dilihat dari aspek ekonomis, harus diakui bahwa kebijakan pengembangan kelapa sawit ini akan memiliki prospek yang sangat besar, bukan hanya ekspor, prospek peningkatan produk CPO (crude palm oil) dan pemasukan devisa negara, namun juga untuk mengakselerasi kesejahteraan masyarakat melalui pembukaan lapangan kerja, penciptaan industri hilir, serta dampak-dampak ikutan yang muncul dari kebijakan ini. Apalagi jika kita mengamati keberhasilan negeri jiran Malaysia yang hingga kini telah mempunyai industri kelapa sawit terbesar di dunia. Selain itu, kebutuhan pasar baik domestik maupun internasional terus meningkat, tampaknya prospek komoditas kelapa sawit sulit untuk ditandingi dengan komoditas lainnya. Teknologi pembangunannya pun relatif sederhana dengan kemungkinan pelibatan masyarakat luas serta hasilnya yang dengan segera dapat dinikmati dipertimbangkan oleh banyak daerah di Kalimantan sebagai sumber ekonomi yang potensial. Bahkan tidak tertutup kemungkinan ada yang berpendapat, bahwa penanaman sawit di Kalimantan jauh lebih selaras lingkungan (environmentally friendly) daripada kegiatan pertambangan (terutama tambang terbuka) yang sama populernya saat ini, terutama bila mampu menghijaukan kembali lahan-lahan hutan yang terdegradasi (lahan kritis). Meskipun demikian, prospek bisnis yang besar bukan sesuatu yang bersifat otomatis, namun harus ditunjang oleh upaya yang sistematis, misalnya adanya pengkajian mengenai peluang pasar internasional, penerapan standarisasi mutu dan sistem keamanan produk kelapa sawit, sertifikasi dan proses pengujiannya, dan sebagainya.

Sebenarnya banyak pihak yang telah menyampaikan masukan terkait dengan pengembangan perkebunan kelapa sawit skala besar di Kalimantan, khususnya di wilayah 
perbatasan. Satu diantaranya adalah WWF Indonesia (2006), antara lain yang perlu dipertimbangkan:

1. Tidak mengkonversi hutan alam dan hutan bernilai konservasi tinggi (HCVF), atau dengan menempatkan kebun sawit di tempat yang tepat (lahan sesuai dan tata ruang sesuai);

2. Revitalisasi areal yang telah ditetapkan sebagai kebun sawit tetapi terlantar (seperti di Kalimantan Barat 1,5 juta Ha. terlantar dan di Kalimantan Timur 300-400 ribu Ha.);

3. Assessment yang komprehensif dan tepat sebelum mengembangkan kawasan perbatasan;

4. Melakukan mosaics plantation (pengembangan komoditas lain yang telah diakrabi masyarakat dan ramah lingkungan);

5. Mengimplementasikan better practices (praktek-praktek pemanfaatan lahan yang terbukti lebih baik).

Untuk itu sudah seharusnya Pemerintah dalam membuat suatu kebijakan mengkomunikasikannya secara terbuka kepada masyarakat baik dampak positif maupun negatif yang bisa ditimbulkan. Pemerintah dan pihak yang mendukung kebijakan ini harus bisa menerima berbagai masukan dan kritikan dari berbagai pihak secara bijak dan mengakui berbagai kekurangan yang ada pada kebijakan serupa sebelumnya yang berakibat negatif (lahan terlantar dan kerusakan lingkungan). Demikian juga pihak-pihak yang menolak, hendaknya menyampaikan secara bijak dan melalui jalur yang sesuai aturan, karena pada dasarnya semua pihak mempunyai tendensi positif dalam hal pengelolaan wilayah perbatasan yaitu meningkatkan kesejahteraan masyarakat di daerah perbatasan dengan tidak merusak lingkungan, serta dapat mengatasi berbagai permasalahan yang ada berkaitan dengan perbatasan.

Komitmen bersama dari seluruh pihak dalam pengelolaan daerah perbatasan inilah yang perlu disepakati bersama. Untuk itu, berbagai pihak baik yang mendukung maupun menentang rencana pembangunan perkebunan kelapa sawit di daerah perbatasan ini hendaknya duduk dalam satu meja dan merumuskan bersama-sama dengan saling menerima masukan dan pendapat untuk kemudian membuat suatu konsep kebijakan yang saling bersinergi demi kepentingan bangsa dan negara.

Adapun beberapa hal yang bisa ditawarkan sebagai solusi guna mencari jalan yang terbaik menanggapi rencana pembangunan perkebunan kelapa sawit di daerah perbatasan ini adalah:

1. Dilakukan pemetaan terlebih dahulu daerah perbatasan secara menyeluruh untuk mengetahui berbagai karakteristik kawasan yang ada, mulai dari luasan wilayah, garis perbatasan, sampai dengan peruntukan kawasan (kawasan lindung dan kawasan budidaya) dan disesuaikan dengan rencana tata ruang dan wilayah baik kabupaten/kota maupun provinsi sehingga jelas yang dimaksud dengan kawasan yang akan dilakukan pembangunan perkebunan kelapa sawit.

2. Dilakukan kajian (studi kelayakan) yang mendalam dan mendetail mengenai berbagai aspek yang menyangkut rencana dan langkah-langkah pembukaan lahan perkebunan ini, mulai dari kawasan mana yang akan dijadikan areal perkebunan, kecocokan lahan, jenis tanaman, pengolahan hasil, hingga dampak negatif yang dapat terjadi terhadap lingkungan untuk dicari jalan keluarnya, sehingga kegagalan dalam program kebijakan sejenis sebelumnya tidak terulang. 
3. Hendaknya dalam pengelolaan daerah perbatasan ini dibuat suatu kebijakan dengan berdasarkan potensi unggulan sumber daya alam (resources base) yang sesuai dengan kawasan tersebut sehingga ekosistem alami dapat lebih terjaga dan tidak memaksakan satu komoditas saja tanpa memperdulikan kecocokan lahannya.

\section{Catatan Penutup}

Dalam suatu pengembangan kebijakan yang dampak dan implementasinya melibatkan banyak pihak dan berdampak luas, dalam hal ini kebijakan pengembangan perkebunan kelapa sawit skala besar di Kalimantan umumnya dan Kalimantan Timur khususnya, hendaknya dilakukan Strategi Pengembangan Kebijakan dengan langkah-langkah yang jelas dan sesuai kebutuhan. Ada beberapa faktor penting dalam suatu pengembangan kebijakan, yaitu adanya kejelasan tujuan dan sasaran, adanya alternatif, adanya kejelasan kriteria pengambilan keputusan dan dalam pengambilan keputusan haruslah secara rasional dengan melihat berbagai aspek yang mempengaruhi kebijakan tersebut.

Tujuan dan sasaran yang jelas perlu ditentukan guna mengetahui persis apa yang hendak dicapai dengan dilakukannya kebijakan tersebut. Pentingnya alternatif sendiri adalah agar terfokus terhadap penyelesaian masalah dan bukan memaksakan suatu kebijakan yang dalam implementasinya justru akan membuat berbagai permasalahan. Selain itu alternatif diperlukan untuk mendorong inovasi dan pencegahan pencemaran \& kerusakan lingkungan, mengurangi risiko jangka panjang serta dapat mengakomodasi partisipasi publik dan beban risiko dapat dibagi dengan semua pihak melalui konsultasi publik yang dilakukan sebagai sarana komunikasi antar stakeholder.

Sedangkan pentingnya kriteria pengambilan keputusan adalah sebagai satu faktor kritis dan menentukan dalam pengembangan kebijakan karena ada kejelasan kriteria yang telah ditentukan dalam menentukan keputusan yang terbaik dan menjadi ukuran dalam pengambilan keputusan. Dan kriteria tersebut sebaiknya disepakati oleh berbagai pemangku kepentingan (stakeholders). Untuk Teknik Pengambilan keputusan dapat dilakukan melalui beberapa pendekatan, diantaranya bentuk pendekatan sistematis:

- Pendekatan Kualitatif

- Pendekatan Kuantitatif

- Pendekatan Ranking, Rating dan Scaling

- Pendekatan Pembobotan (weighting)

- Pendekatan Kombinasi Pembobotan - Ranking, Rating dan Scaling

Sebagai contoh dalam pengembangan kebijakan yang hubungannya dengan kebijakan pengembangan kelapa sawit adalah dengan tujuan meningkatkan perekonomian masyarakat dan negara melalui sektor non migas, sedangkan sasarannya adalah mengembangkan sektor perkebunan. Untuk mencapai tujuan dan sasaran tersebut perlu dicari beberapa alternatif pilihan yang dapat dilakukan, diantaranya adalah pembukaan lahan perkebunan kelapa sawit, perkebunan kakao, perkebunan karet, dan sebagainya yang disesuaikan dengan areal/lahan yang tersedia sehingga sesuai dengan Rencana Tata Ruang dan Wilayah (RTRW). 
Rencana Tata Ruang dan Wilayah sendiri harus berdasarkan AMDAL yang sesuai, dengan memperhatikan kemungkinan dampak yang terjadi, jika dampak tersebut dapat ditanggulangi barulah dapat dikeluarkan perijinannya. Dalam UU No.41/1999 Pasal 23, arti sesuai dengan Tata Ruang sendiri adalah tidak boleh di daerah terlarang (zona inti pada tanaman masyarakat, zona rimba pada taman nasional, hutan cagar alam) dan sesuai dengan tata guna lahan (land use planning). Sedangkan AMDAL adalah studi kelayakan lingkungan suatu proyek (selain kelayakan ekonomi \& teknis) yang diberlakukan untuk kegiatan yang berdampak penting (significant impact) melalui kajian ilmiah untuk pengambilan keputusan di tingkat proyek dan bersifat kajian site specific dan project specific. Selain itu ada partisipasi masyarakat dalam pengambilan keputusan. Jadi, AMDAL merupakan salah satu alat/instrumen pengelolaan lingkungan hidup untuk membantu pengambilan keputusan apakah layak atau tidaknya suatu kegiatan (proyek) dari sisi lingkungan. Dan AMDAL bukanlah alat untuk menentukan kelayakan kebijakan di tingkat makro ataupun alat untuk pembenaran pelanggaran tata ruang.

Jadi, dalam hal pengembangan kebijakan kelapa sawit skala besar di Kalimantan, khususnya Kalimantan Timur diperlukan langkah-langkah yang jelas dan terarah dengan tujuan dan sasaran yang jelas pula, tidak tergesa-gesa dalam menetapkan suatu kebijakan apalagi pengembangan skala besar ini juga diarahkan ke daerah perbatasan, sedangkan kecocokan lahan di daerah perbatasan sendiri sangat diragukan untuk kelapa sawit karena daerahnya yang berbukit-bukit dan daerah resapan air yang sangat penting bagi kehidupan manusia, belum lagi kekayaan alam dan keanekaragaman hayati yang ada sangat berharga. Sementara itu, lahan kritis dan rusak yang ada masih sangat luas dan perlu penanganan segera karena dampaknya semakin kita rasakan tidak hanya didaerah hulu tetapi juga sampai perkotaan seperti banjir yang semakin meluas.

Di lain sisi, harus diakui bahwa komoditas kelapa sawit merupakan komoditas yang dapat menjadi unggulan dimana peluang dan prospeknya ke depan sangat besar dan menjanjikan dan merupakan sumberdaya alam yang dapat diperbaharui (renewable). Namun, hendaknya proyek perkebunan kelapa sawit ini sendiri mempunyai aturan-aturan dan batasan dalam pelaksanaannya dilapangan karena dikhawatirkan jika tidak ada aturan yang jelas dan tegas, perkebunan kelapa sawit ini bisa jadi akan masuk ke kawasan lindung dan cagar alam yang dapat berdampak negatif baik bagi kelestarian alam dan juga manusia akibat terganggunya ekosistem alam.

Kini, semuanya tergantung pada para pengambil keputusan dan pembuat kebijakan apakah tujuannya memang untuk kesejahteraan rakyat dan meningkatkan harkat dan martabat bangsa tanpa melupakan kelestarian alam dan lingkungan yang menjadi tempat tinggal manusia. Atau hanya ingin memaksakan kebijakan-kebijakan yang hanya dianggap benar tanpa memikirkan dampaknya terutama dampak negatif dan langkah penanganan masalah tersebut. Tapi, apakah semua lahan harus ditanami kelapa sawit dan apakah harus di daerah perbatasan sementara banyak lahan kritis yang lebih cocok ditanami sawit daripada daerah perbatasan, semuanya tergantung pada pemegang kewenangan dan pembuat kebijakan. 


\section{Daftar Bacaan}

BAPPEDA Prov. Kaltim, 2006, Profil Pembangunan Kalimantan Timur, Samarinda: BAPPEDA Prov. Kaltim.

Djoekardi, Arie D.D., 2006, Review Pengembangan Kelapa Sawit Skala Besar di Kalimantan, makalah disampaikan pada Seminar Nasional Forum SANKRI "Pengembangan Kelapa Sawit Skala Besar: Perspektif Kebijakan dan Kelayakan Pasar", Samarinda: PKP2A III LAN.

Kaltim Post, DPR Minta Kaji Ulang Rencana Pembangunan Jalan Perbatasan, Selasa, 18 Oktober 2005. , Kawasan Perbatasan Jadi Pusat Perkebunan: Disbun Lakukan Kajian Teknis, Senin, 19 Desember 2005. , Panglima TNI Tinjau Perbatasan, Gubernur: Sawit Sejuta Hektare Jalan Terus, Rabu, 22 Maret 2006. , Pemprov Tetap Jalan, Berkaca pada Malaysia, Selasa, 25 Oktober 2005. , Soal Rencana Perkebunan Sawit di Perbatasan, Said Amin: Teruskan, tetapi Pakai Skala Prioritas, Selasa, 7 Maret 2006.

Khakim, Abdul, 2005, Pengantar Hukum Kehutanan Indonesia Dalam era Otonomi Daerah, Bandung: PT. Citra Aditya Bakti.

Kompas, Wapres: Pemerintah Serius Bangun Daerah Perbatasan, Senin, 12 September 2006.

Koran Tempo, Rencana Sabuk Sawit di Perbatasan, Jum'at, 16 Desember 2005.

Sa'id, E. Gumbira, 2006, Prospek Bisnis dan Pemasaran Kelapa Sawit Indonesia, makalah disampaikan pada Seminar Nasional Forum SANKRI "Pengembangan Kelapa Sawit Skala Besar: Perspektif Kebijakan dan Kelayakan Pasar", Samarinda: PKP2A III LAN.

Sardjono, Mustofa Agung, 2006, Makalah: Analisis Strategi Kebijakan Pengembangan Kelapa Sawit Skala Besar di Kalimantan: Peluang dan Tantangan ke depan.

Tribun Kaltim, Wilayah Perbatasan tak Cocok untuk Sawit, Rabu, 30 November 2005. , 12.000 Ha Lahan Sawit Terlantar, Rabu, 30 November 2005 , Menhut Menentang Pembukaan Sawit di Perbatasan, Senin, 12 Desember 2005. , MS Kaban: Sawit Perbatasan Jalan Terus, Rabu, 28 Desember 2005. 
, Sawit akan Batasi RI-Malaysia: Disbun Kaltim Belum Lakukan Pengkajian, Senin, 6 Pebruari 2006.

, Pangdam Dukung Penuh Sawit di Perbatasan, Jum'at, 10 Maret 2006.

, DPD Kaltim Surati Presiden: Terkait Penolakan Sawit di Perbatasan, Senin, 6 Maret 2006.

, Stop Dulu Izin Sawit: Sampai Ada Pertanggungjawaban Terlantarnya 3,5 Juta Ha Lahan Sawit, Tuntutan Forum Satu Bumi dalam Unjuk Rasa, Jum'at, 7 April 2006.

, Witoelar: Saya Tidak Tahu, Rencana Proyek Sawit di Perbatasan Kalimantan-Malaysia Minta Agar Pelaksanaannya tak Merusak Lingkungan, Selasa, 25 April 2006.

Undang Undang Republik Indonesia Nomor 41 tahun 1999 tentang Kehutanan.

Keputusan Menteri Kehutanan Nomor SK.55/Menhut-VII/2004 tentang Rencana stratejik pengelolaan kawasan hutan wilayah perbatasan Indonesia - Malaysia di Kalimantan. 